DOI: http://dx.doi.org/10.30641/ham.2021.12.305-324

\title{
PEMBATASAN HAK UNTUK BERGERAK (RIGHT TO MOVE) MELALUI LARANGAN MASUK DAN PEMBATASAN PERJALANAN SELAMA PENYEBARAN VIRUS COVID-19 MENURUT HUKUM INTERNASIONAL DAN HUKUM INDONESIA \\ (Limitation Of The Rights To Move Through Entry Regulation And Travel Restrictions During Covid-19 Virus Outbreak Under International Law And Indonesian Law)
}

\author{
Ari Wirya Dinata, M. Yusuf Akbar \\ Fakultas Hukum Universitas Bengkulu \\ aridinata@unib.ac.id
}

\begin{abstract}
The World Health Organization (WHO) declared Covid-19 as a Pandemic on March 11, 2020. Several countries have already issued several policies to decline the spread of the virus. One of these policies is entry regulation and travel restrictions. This policy aims to prevent the transmission and spread of the virus due to human movement. On the other hand, human rights conventions protect the right to move and enter a country and prohibit discrimination. This paper reviews the perspective of international law concerning entry regulation policy and discusses Indonesia's domestic policy in dealing with the outbreak. This paper uses the normative juridical method with secondary data. It consists of primary legal materials, secondary legal materials, and tertiary legal materials. This paper summarizes that state policy regarding entry regulation and travel ban restrictions are allowed under international law. It had already made an impact by reducing the number of corona outbreaks across national borders. However, this policy may violate human rights if it does not refer to applicable legal provisions and other human rights conventions. This paper suggests that policymakers be aware and careful in using the entry regulation policy.
\end{abstract}

Keywords: human rights; entry regulation and travel ban restriction; covid-19.

\begin{abstract}
ABSTRAK
Organisasi Kesehatan Dunia (WHO) menyatakan Covid-19 sebagai Pandemi pada 11 Maret 2020. Sejumlah negara telah membuat berbagai kebijakan untuk menekan penyebaran virus tersebut. Salah satu kebijakan tersebut adalah regulasi masuk dan pembatasan perjalanan. Kebijakan ini dipandang perlu untuk mencegah penularan dan penyebaran virus secara masif akibat pergerakan manusia. Di sisi lain, konvensi hak asasi manusia memberikan perlindungan terhadap hak untuk bergerak dan memasuki suatu negara dan melarang tindakan diskriminasi. Tulisan ini mengkaji perspektif hukum internasional tentang kebijakan masuk dan pembatasan perjalanan serta membahas kebijakan domestik Indonesia dalam menanggulangi wabah korona. Penelitian ini menggunakan metode yuridis normatif, dengan data sekunder yaitu bahan hukum primer, bahan hukum sekunder dan bahan hukum tersier. Tulisan ini merangkum bahwa kebijakan negara mengenai pengaturan masuk dan pembatasan larangan bepergian merupakan sesuatu yang dibolehkan menurut hukum internasional. Hal ini berdampak pada pengurangan jumlah wabah korona lintas batas negara. Meskipun demikian, kebijakan ini mungkin melanggar hak asasi manusia jika tidak mengacu pada ketentuan hukum yang berlaku seperti konvensi hak asasi manusia. Tulisan ini menyarankan kepada para pembuat kebijakan untuk berhati-hati dalam menggunakan kebijakan entry regulation.
\end{abstract}

Kata Kunci: hak asasi manusia; pembatasan perjalanan dan masuk; covid-19. 


\section{PENDAHULUAN}

Pada 11 Maret 2020, Organisasi Kesehatan Dunia (WHO) menyatakan bahwa virus Covid-19 pertama kali teridentifikasi pada Desember 2019 di Wuhan, Cina. Penyebaran virus ini telah mencapai level menjadi pandemi global. Dengan tingkat penyebaran yang cukup tinggi dan mengkhawatirkan, WHO menyerukan kepada negara-negara untuk mengambil tindakan sesegera dan seagresif mungkin untuk menghentikan penyebaran virus. Organisasi Kesehatan Dunia (WHO), Pada tanggal 11 Maret 2020 juga menyatakan Covid-19 sebagai pandemi global, Dimana penyebaran Covid-19 mempengaruhi lebih dari 100 negara dalam penyebarannya. ${ }^{1}$ Selang kurang dari satu bulan, Pada tanggal 1 April 2020, WHO melaporkan bahwa Covid-19 telah terdeteksi di lebih dari 200 negara dan wilayah, dengan sekitar 823.626 kasus yang dikonfirmasi dan 40.598 kematian. $^{2}$

Untuk mengurangi penyebaran pandemi ini, semua negara mengambil berbagai langkah kebijakan seperti memberlakukan pembatasan perjalanan internasional, larangan semua pengunjung asing dan pembatasan perjalanan dari berbagai tempat dengan kasus yang dikonfirmasi. Pembatasan lain dilakukan seperti menangguhkan semua penerbangan komersial internasional, pelancong yang menjalani karantina 14 hari dan menangguhkan visa. UNWTO menemukan bahwa 93\% destinasi di Eropa telah sepenuhnya menutup perbatasan untuk pariwisata internasional. Di Amerika proporsi ini mencapai $82 \%$, di Asia dan Pasifik 77\%, di Timur Tengah 70\% dan Afrika $60 \%$ sehingga jumlah penumpang turun tajam. IATA memperkirakan krisis Covid-19 akan menyebabkan pendapatan penumpang maskapai penerbangan global turun sebesar US\$314 miliar pada 2020 atau sekitar 55\% dibandingkan 2019.

1 Edward Livingston, Karen Bucher, dan Andrew Rekito, "Coronavirus Disease 2019 and Influenza 2019-2020," JAMA - Journal of the American Medical Association 323, no. 12 (2020): 1122.

2 Wang Huei Sheng, "Coronavirus disease 2019 (covid-19)," Journal of Internal Medicine of Taiwan 31, no. 2 (2020): 61-66.
Sementara itu, maskapai di kawasan Asia Pasifik mengalami penurunan pendapatan terbesar yakni US\$113 miliar pada 2020 atau 50\% dibandingkan 2019. ${ }^{3}$

Akibat pandemi Covid-19, IATA juga memperkirakan permintaan transportasi penerbangan yang diukur dalam kilometer kargo ton (CTKs) pada Februari 2020, turun 1,4\% dibandingkan periode yang sama tahun 2019 . UNWTO juga telah melaporkan bahwa pandemi Covid-19 telah menyebabkan penurunan 22\% dalam kedatangan wisatawan internasional selama kuartal pertama tahun 2020 dan dapat menurun sebesar 60\%-80\% sepanjang tahun 2020 . Data terbaru dari UNWTO menunjukkan bahwa kedatangan wisatawan di bulan Maret turun sebesar 57\% setelah penguncian dimulai di banyak negara, dan pembatasan perjalanan yang luas, penutupan bandara, dan perbatasan nasional. Ini berarti hilangnya 67 juta kedatangan internasional dan sekitar US\$ 80 miliar pendapatan (ekspor dari pariwisata). Jika penurunan ini berlanjut hingga $80 \%$ dibandingkan tahun 2019, diperkirakan wisatawan mancanegara akan turun 850 juta menjadi 1,1 miliar, hilangnya pendapatan ekspor US\$ 910 miliar hingga US\$1,2 triliun, 100 hingga 120 juta pekerjaan berisiko dimana hal ini tentu mengkhawatirkan ${ }^{4}$

Sementara di Indonesia, berdasarkan data Badan Pusat Statistik (BPS) dilaporkan bahwa rasio gini pada September 2020 mengalami peningkatan dari 0,380 menjadi 0,385 . Lalu, angka kemiskinan juga meningkat dari 9,22 persen menjadi 10,19 persen akibat dampak pandemi Covid-19. Berdasarkan data September 2019 tersebut, disimpulkan bahwa penduduk miskin di Indonesia naik sebesar 2,76 juta. Peningkatan ini terjadi lebih tinggi di daerah perkotaan daripada di pedesaan. ${ }^{5}$ Peningkatan angka kemiskinan dan

3 "Impact assessment of the COVID-19 outbreak on international tourism | UNWTO," diakses Juni 18, 2021, https://www.unwto.org/impact-assessment-ofthe-covid-19-outbreak-on-international-tourism.

4 Ibid

5 "Rasio Gini 2020 Naik Jadi 0,385, Covid-19 Buat Ketimpangan Makin Lebar - Ekonomi Bisnis.com," 
rasio gini ini tentunya merupakan akibat dari kebijakan pembatasan berskala besar (PSBB) yang diambil oleh Pemerintah dimana salah satunya adanya pembatasan bergerak orang.

Pembatasan hak untuk bergerak akan melambankan laju pergerakan ekonomi rakyat. Keadaan ini seyogyanya mengiring Pemerintah pada keadaan dilema dan simalakama yaitu antara menjaga pertumbuhan ekonomi atau menekan laju penyebaran Covid-19. Pemerintah seakan dihadapkan pada Fetakompi antara memilih mengedepankan ekonomi atau kesehatan. Meskipun, kedua hal ini penting dan perlu diperhatikan. Oleh karena itu, Pemerintah harus dapat memformulasikan kebijakan yang seimbang antara kedua hak tersebut dan tanpa mengabaikan satu diantaranya. Tentu, tidak mudah mencari titik keseimbangan (equilibrium point) pemenuhan hak ekonomi dan hak Kesehatan. Pilihan pembatasan hak bergerak yang dipilih oleh Pemerintah tentunya memberikan dampak baik guna menekan jumlah penyebaran virus korona. Namun, di sisi lain, jika kebijakan ini terus digunakan tanpa ada batas waktu dan solusi alternatif lainnya, tidak menutup kemungkinan akan memunculkan masalah sosial baru seperti kemiskinan, kriminalitas dan psikologi.

\section{Deklarasi Universal tentang HAM} Tahun 1948 adalah puncak perjuangan HAM internasional, tindakan-tindakan yang dilakukan oleh komunitas internasional ini tidak terlepas dari idealisme demokrasi dan konsep negara hukum (the rule of law), sebagai dari bangunan dasar dari tatanan dunia. ${ }^{6}$ Demokrasi sebagai paham kedaulatan rakyat menempatkan rakyat pada centrum kekuasaan yang harus diprioritaskan pemenuhan hak dan kewajibannya. Begitu pula dengan ciri negara hukum (the rule of law) yang memiliki karakteristik jaminan hak asasi manusia dalam bingkai hukum.

diakses Juni 18, 2021, https://ekonomi.bisnis.com/ read/20210215/9/1356258/rasio-gini-2020-naik-jadi0385-covid-19-buat-ketimpangan-makin-lebar.

6 Jawahir Thontowi dan Pranoto Iskandar, 2006, Hukum Internasional Kontemporer, (Bandung: Refika Aditama), 25.
Ada dua teori mendasar dalam konsep pemenuhan HAM yaitu teori berdasarkan prinsip kebebasan (liberty) di negara-negara common law dan teori berdasarkan prinsip hak (rights) di negaranegara di civil law. Kedua-duanya mengarah pada hubungan antara negara dan individu. Berupaya mengatur batasan intervensi pemerintah dalam kehidupan pribadi individu. Singkat kata, teori liberty menginginkan bahwa individu bebas dari intervensi sewenang-wenangan negara, adapun teori rights mendasarkan pada hak-hak yang melekat pada individu yang harus dihormati oleh negara. ${ }^{7}$

Hak untuk bergerak (freedom of movement) sudah dikenal sebagai narasi tentang hak individu untuk bermobilisasi dan memasuki negara lain, atau dilihat sebagai cara lain untuk dapat berkeliling dan masuk ke negara lain tanpa adanya pembatasan imigrasi. Hak untuk bergerak (freedom of movement) muncul dalam tiga manifestasi dalam universal deklarasi hak asasi manusia dan Konvensi Sipil dan Politik. Sebagaimana dikutip oleh Jane McAdam yaitu first, it encompasses the right to move freely within a country and to choose one's place of residence there, secondly, it includes the right to cross an international border, expressed as the right to leave any country, including one's own. Thirdly, it extends to the right to return to one's country. ${ }^{8}$ Sehingga pada intinya hak untuk bergerak merupakan hak asasi setiap individu untuk berpindah/mutasi dari satu wilayah ke wilayah lain di bumi tanpa adanya pembatasan yang melanggar hak asasi manusia dan dilarang diskriminatif. ${ }^{9}$

$7 \quad$ Sefriani,2016, Peran Hukum Internasional Dalam Hubungan Internasional Kontemporer, (Jakarta: Rajawali Press), 321.

8 Jane Mcadam, "An Intellectual History of Freedom of Movement in International Law," Melbourne Journal of International Law 12, no. 1 (2011): 1-30, http://law.unimelb.edu.au/_ data/assets/pdf_file/0011/1686926/McAdam. pdf.

9 Antonio Guterres, "We are all in this Together: Human Rights and COVID-19 Response and Recovery | United Nations," diakses Agustus 3, 2021, https://www.un.org/ en/un-coronavirus-communications-team/we-are-alltogether-human-rights-and-covid-19-response-and. 
Namun keadaan penyebaran Covid-19 menyebabkan pemenuhan hak untuk bergerak ini memerlukan adanya pembatasan. Sejalan dengan Prinsip Siracusa yang diadopsi oleh UN Economic and Social Council 1988 dan Komentar Umum UN Human Rights Committee menyebutkan dalam keadaan darurat maka kebebasan bergerak/ berpindah dapat dilakukan dengan memberikan panduan otoritatif. Sebab setiap tindakan yang diambil untuk melindungi penduduk yang membatasi hak dan kebebasan masyarakat harus sah, perlu dan proporsional. Keadaan darurat atas kebebasan bergerak/berpindah tersebut harus memiliki durasi dan mempertimbangkan dampak bagi populasi tertentu dan yang terpinggirkan. ${ }^{10}$ Dalam prakteknya, prinsip ini juga diaplikasikan dalam penanggulangan darurat Kesehatan. Dalam Pendapat umum (general comment) Pasal 4 ICCPR menyebutkan bahwa negara yang memberlakukan pembatasan harus merujuk dan menyesuaikan dengan hukum domestik masing-masing. ${ }^{11} \mathrm{Di}$ Indonesia, pemberlakukan pembatasan hak untuk bergerak diatur didalam berbagai peraturan perundang-undangan.

Meskipun hampir sebagian besar negara melakukan pembatasan hak untuk bergerak di negaranya masing-masing baik bagi warga negara asing maupun warga negaranya sendiri dan sejumlah instrumen hukum memang membolehkan dan memberi ruang untuk ditafsir adanya pembatasan hak atas berpindah dan bergerak yang sah menurut hukum. Namun dalam mengambil tindakan tersebut harus dilakukan secara hati-hati, dan penuh kebijaksanaan. Bahkan

10 "Human Rights Dimensions of COVID-19 Response Human Rights Watch," diakses April 22, 2021, https://www.hrw.org/ news/2020/03/19/human-rights-dimensionscovid-19-response\#_Toc35446577.

11 International Covenant on Civil and Political Rights, "General comment no. 29 states of emergency (article 4)," diakses Agustus 3, 2021, http://docstore.ohchr.org/ SelfServices/FilesHandler.ashx?enc $=6 \mathrm{QkG} 1 \mathrm{~d} \% 2 \mathrm{FPP}$ RiCAqhKb7yhsjYoiCfMKoIRv2FVaVzRkMjTnjRO \%2Bfud3cPVrcM9YR0iix49nlFOsUPO4oTG7R\%2F o7TSsorhtwUUG\%2By2Pts1Yr5BldM8DN9shT8B8N pbsC\%2B7bODxKR6zdESeXKjiLnNU\%2BgQ\%3D $\% 3 \mathrm{D}$ di negara-negara Eropa memiliki standar yang baku dan relatif sama untuk negara-negara yang bergabung dalam suatu organisasi internasional. ${ }^{12}$

Dalam hukum internasional di bidang Hak Asasi Manusia (HAM) mengatur bagaimana regulasi internasional memberikan perlindungan HAM dimasa pandemi. Hal ini tercantum dalam Pasal 4 ayat (1) Kovenan Internasional tentang Hak Sipil dan Politik (ICCPR) yaitu menjamin hak setiap orang atas perlakuan standar kesehatan tertinggi dan mewajibkan pemerintah untuk mengambil langkah-langkah untuk mencegah ancaman terhadap kesehatan masyarakat dan untuk memberikan perawatan medis kepada mereka yang membutuhkan. Hukum internasional juga mengakui bahwa dalam konteks ancaman kesehatan masyarakat yang serius dan keadaan darurat yang mengancam kehidupan bangsa, pembatasan beberapa hak dapat dibenarkan jika memiliki dasar hukum dan memenuhi parameter/ kriteria tertentu, berdasarkan bukti ilmiah, durasi yang terbatas, menghormati martabat manusia, tunduk pada hukum, dan proporsional untuk mencapai tujuan. ${ }^{13}$

Dalam mengendalikan penyebaran virus Covid-19 ini, banyak negara yang menerapkan kebijakan yang membuat pembatasan hak untuk bergerak seperti perintah untuk hanya berdiam diri di rumah saja. Kebijakan tersebut dianggap dapat menurunkan penyebaran virus dan mengurangi resiko penyebaran virus lebih luas. Namun, kebijakan ini menimbulkan dampak yang menganggu ke berbagai bidang seperti pekerjaan, mata pencaharian, akses layanan, termasuk layanan kesehatan, makanan, air dan pendidikan. Tentu, jika hal ini dilaksanakan dengan waktu yang lama, tidak menutup kemungkinan akan

12 Wouter Van Ballegooij dan Cecilia Navarra, "An EU mechanism on democracy, the rule of law and fundamental rights," last modified September 2020, diakses Juli 30, 2021, https://www.europarl.europa. eu/RegData/etudes/STUD/2020/654186/EPRS STU(2020)654186_EN.pdf.

13 Vitit Muntarbhorn, "The International Covenant on Civil and Political Rights (ICCPR) and Thailand," The Core Human Rights Treaties and Thailand 999, no. 14668 (2016): 141-194. 
menimbulkan masalah yang lebih besar dari virus Covid-19 itu sendiri. Lalu, di saat yang bersamaan, beberapa pemerintahan di beberapa negara di awal penanganan menyangkal Covid-19 telah masuk ke negaranya. Lebih lanjut, bahkan banyak pihak yang mencoba mengaitkan penanganan Covid-19 dengan rezim pemerintahannya karena tidak berhubungan dengan keberhasilan respons dalam penanganan Covid-19. ${ }^{14}$

Walaupun dalam hal tertentu, hukum internasional membolehkan pembatasan hak untuk bergerak demi alasan keamanan seperti yang dicantum dalam Pasal 15 ECHR atau Pasal 4 ayat 1 ICCPR. Pembatasan atas hak tersebut boleh dilakukan jika diperlukan dengan memperhatikan prinsip proporsional, tidak bersifat diskriminatif dan berdasarkan bukti ilmiah. ${ }^{15}$ Dengan kata lain, hukum internasional mensyaratkan sejumlah parameter yang harus dipenuhi dalam kebijakan pembatasan perpindahan orang antar negara. Oleh karena itu, kebijakan tersebut harus dilakukan secara hati-hati karena berpotensi melanggar hak asasi manusia, terutama apabila tidak patuh dengan aturan hukum internasional.

Perdebatan antara hak asasi manusia yang mana yang dikedepankan atau diprioritaskan dalam penanganan Covid-19 telah menjadi diskursus yang panjang dan penuh dengan dinamika. Hak atas hidup yang melekat pada hak atas kesehatan menjadi alasan melegalkan tindakan dengan membuat larangan masuk ke negaranegara yang memiliki jumlah kasus relatif tinggi ataupun penutupan. Hal ini dilakukan dengan alasan perlindungan warga negara di wilayahnya dari negara manapun, baik negara rendah kasus penyebarannya, maupun negara dengan jumlah kasus tinggi dan penanganan yang lemah.

Sebagai contoh, Indonesia mengakui hak asasi manusia untuk melakukan perjalanan dan

14 Ibnu Sina Chandranegara, "Diantara yang terbaik dan terburuk dalam merespon Covid-19 di Asia Tenggara," in Makalah pada webinar New Normal dalam Perspektif Hukum (Solo: Universitas Sebelas Maret Surakarta, 2020).

15 Pasal 4 ayat 1 Perjanjian Internasional Tentang HakHak Sipil dan Politik bergerak (freedom of movement), tetapi di sisi lain, Indonesia juga memiliki kewajiban asasi untuk memastikan hak atas Kesehatan bagi warga negaranya dalam membuat kebijakan menghadapi pandemi. Ketentuan tersebut dapat ditemukan didalam Pasal 27 ayat (1) Undang-Undang Nomor 39 Tahun 1999 tentang Hak Asasi Manusia juncto Pasal 28 huruf A Undang-Undang Dasar NRI 1945. Setiap negara termasuk Indonesia harus mampu melakukan penilaian dan pengukuran atas setiap kebijakannya terhadap potensi pelanggaran HAM yang mungkin terjadi.

Salah satu teori yang membahas tentang menilai keadilan dalam kebijakan publik adalah pemikiran John Rawls tentang konsep Maximin (Maximum Minimorum) yaitu setiap kebijakan yang dibuat sebaiknya menimbang seberapa besar manfaat yang dapat dihasilkan dan mudarat yang akan ditimbulkan. Apabila kebijakan yang dibuat membuahkan keuntungan yang lebih besar dari kerugian yang terjadi, kebijakan tersebut dapat dikatakan baik. Hal ini vis versa apabila kebijakan yang dibuat menimbulkan dampak kerugian yang massif dan besar dibandingkan manfaatnya, maka seharusnya kebijakan tersebut tidak dipilih. ${ }^{16}$

Penilaian atas kebijakan publik dan hukum yang diambil dalam masa pandemik ini perlu dinilai dan diuji dari segi pemenuhan hak asasi manusia. Kerap kali, aspek pemenuhan hak asasi manusia terabaikan manakala pemerintah membuat kebijakan dalam menghadapi keadaan darurat, baik bencana alam maunpun non-alam. Sementara, dalam konsep hak asasi manusia, pemenuhan HAM tidak mengenal situasi karena dalam keadaan apapun HAM patut dipenuhi dan dihormati.

Sebagaimana dinukilkan oleh Mahfud MD, sejatinya, ada dua jenis peraturan perundangundangan yaitu peraturan perundang-undangan yang responsif yaitu yang mampu menjawab kebutuhan hukum publik dan peraturan perundangundangan yang non-responsif (ortodoks) yaitu yang tidak mampu menjawab tantangan dan

16 John Rawls, "Justice as Fairness" (Bandung: Nusamedia, 1999), 219. 
bersifat konservatif. ${ }^{17}$ Oleh karena itu, tantangan ini yang dihadapi dan perlu ditaklukan oleh pembuat kebijakan dalam menciptakan regulasi penanganan pandemik tanpa harus mengabaikan pemenuhan hak asasi manusia. Kebijakan hukum (legal policy) atau garis resmi kebijakan hukum harus sejalan dan mengacu kepada hukum tertinggi (supreme law of the land).

Kebaruan dalam tulisan ini adalah mengkaji pengaturan mengenai pembatasan perjalanan dan pembatasan masuk dalam kacamata hukum internasional vis a vis hukum domestik Indonesia dalam pengaturan perundang-undangan. Tulisan ini mengulas tentang instrumen hukum internasional yang berkaitan dengan kebebasan bergerak dan instrumen hukum nasional Indonesia tentang hal yang sama.

\section{METODE PENELITIAN}

Tulisan ini menggunakan metode penulisan normatif dengan pendekatan peraturan perundangundangan dan konsep yang berkaitan dengan tema yang diangkat. Adapun data yang digunakan dalam penulisan ini berupa data sekunder yang bersumber dari tiga bahan hukum yaitu: pertama, bahan hukum primer yaitu instrumen hukum internasional yang relevan, peraturan perundangundangan yang berlaku dan putusan pengadilan. Kedua, bahan hukum sekunder, berupa hasil penelitian, buku dan publikasi yang berkaitan dengan isu ini dan ketiga, bahan hukum tersier yaitu temuan dan informasi yang bertalian dan mendukung penyempurnaan penulisan ini seperti media cetak, buletin, majalah dan lain-lain. Analisa dalam tulisan ini bersifat deskriptif-analitik yaitu menggambarkan mengenai instrumen hukum internasional yang berkaitan dengan larangan pembatasan masuk dan larangan perjalanan serta menggambarkan langkah atau kebijakan hukum yang sudah dilakukan oleh Indonesia. Selanjutnya, analisa instrument hukum dilakukan terkait dengan menggunakan pendekatan peraturan perundangundangan (statutory approach)

17 Mahfud MD, "Politik Hukum di Indonesia" (Jakarta: Rajawali Press, 2009), 7.

\section{PEMBAHASAN}

$\begin{array}{llrr}\text { A. } & \begin{array}{l}\text { Pembatasan } \\ \text { Berdasarkan }\end{array} & \text { Hak untuk } & \text { Bergerak } \\ \text { Internasional } & & \text { Hukumen }\end{array}$

Hukum Internasional memberikan panduan dalam menangani pandemi Covid-19. Banyak perjanjian internasional yang telah mengatur berbagai aspek dalam menangani suatu pandemi. Hukum Internasional juga memberikan panduan dalam mengatur hak-hak asasi bagi masyarakat internasional dan bagaimana cara yang paling tepat bagi negara-negara untuk mengatasi pandemi. Sebagai contoh, yaitu Konvensi Uni Eropa mengenai Hak Asasi Manusia (ECHR) yang merupakan suatu konvensi internasional yang mengikat negara-negara Uni Eropa yang dijadikan sebagai acuan instrumen ketertiban publik bagi anggota negara Uni Eropa. Konvensi Batasan-batasan tersebut masih dapat diterima di waktu normal. ${ }^{18}$ Walaupun di waktu normal tetap saja ada hak yang memang tidak dapat dikurangi dalam ECHR seperti hak untuk hidup, hak untuk bebas dari penyiksaan dan sanksi hukuman yang tidak manusiawi, hak untuk bebas dari perbudakan dan hak untuk tidak boleh dihukum jika tidak ada hukumnya. Batasan-batasan inilah, baik di waktu normal ataupun krisis, tetap tidak dibolehkan untuk dikurangi. Krisis Covid-19 memang bukanlah waktu di masa normal. Dalam retorika Presiden Prancis Emmanuel Macron, ia mengatakan bahwa di masa pandemi Covid-19 ini seperti "kita sedang berperang". ${ }^{19}$ Dalam Konvensi ECHR, diberikan kewenangan negara untuk mengecualikan pemenuhan HAM

18 Christoph Schreuer, "Derogation of Human Rights in Situations of Public Emergency: The Experience of the European Convention on Human Rights Derogation of Human Rights in Situations of European Convention on Human Rights," The Yale Journal of World Public Order 9, no. 1 (1982): 113-132, http://digitalcommons. law.yale.edu/yjil/vol9/iss1/6.

19 'We are at war': France imposes lockdown to combat virus, diakses 9 April 2021, https://www.reuters.com/article/us-healthcoronavirus-macron-restriction/we-are-at-warfrance-imposes-lockdown-to-combat-virusidUSKBN2133G5 
warganya jika negara dalam keadaan darurat. Pasal 15 ECHR mengatur mengenai pembatasan hak pada saat darurat, mengizinkan negara pada saat perang atau keadaan darurat publik lainnya yang mengancam kehidupan Bangsa [..] untuk mengambil tindakan yang menyimpang dari kewajibannya...' ${ }^{20}$ Ketentuan serupa dapat ditemukan di Pasal 4 (1) Kovenan Internasional tentang Hak Sipil dan Politik (ICCPR), Pasal 27

(1) Konvensi Amerika tentang Hak Asasi Manusia (ACHR), atau Pasal 4 Piagam Arab tentang Hak Asasi Manusia. Satu-satunya regulasi yang tidak memperkenankan pembatasan adalah Piagam Afrika yang tidak memuat ketentuan tentang pengurangan/pembatasan hak. Komisi Afrika menyimpulkan bahwa tidak ada pembatasan yang mungkin dilakukan. ${ }^{21}$ Kemungkinan untuk melakukan pembatasan hak pada saat darurat tidak menggantikan batasan yang diizinkan atas hak asasi manusia. Jika tanpa menggunakan tindakan yang membatasi hak-hak, sebaiknya hal tersebutlah yang dilakukan.

Emilie Hafner-Burton dan kawan kawan mendefinisikan derogation (pengurangan/ pembatasan) sebagai "tindakan rasional yang dilakukan terhadap ketidakpastian, yang memungkinkan Pemerintah untuk mengulur waktu dan ruang bernafas dengan menggunakan hukum untuk mengatur masyarakat dan memerangi krisis dengan membatasi sementara kebebasan sipil dan politik". ${ }^{22}$ Sedangkan, klausul derogasi, menurut Gerald L. Neuman, bertentangan dengan gagasan tentang hak asasi manusia, tetapi dapat berkontribusi pada perlindungan efektif bagi manusia. ${ }^{23}$ Memang, di satu sisi, negara

20 William A. Schabas, "The European Convention on Human Rights: A Commentary" (2015): 1440 .

21 International Justice, "Civil Society Access to International Oversight Bodies African Commission on Human and Peoples ' Rights" (n.d.).

22 Audrey Lebret, "COVID-19 pandemic and derogation to human rights," Journal of Law and the Biosciences 7, no. 1 (Juli 25, 2020): 1-15, diakses April 9, 2021, https://academic.oup.com/ jlb/article/doi/10.1093/jlb/lsaa015/5828398.

23 Audrey Lebret, "COVID-19 pandemic and memiliki kewajiban untuk melindungi hak untuk hidup, ${ }^{24}$ yang mungkin dapat dijadikan justifikasi dalam membatasi beberapa hak asasi manusia lainnya.

\section{B. Situasi Darurat Menurut Hukum Internasional}

Seperti dikatakan sebelumnya, hukum internasional memberikan kelonggaran bagi negara-negara untuk membatasi hak-hak asasi bagi warganya jika dalam situasi darurat yang membahayakan. Oleh karena itu, penilaian terhadap situasi tersebut dapat dibebankan kepada negara. Salah satu contoh lagi dari Konvensi Uni Eropa Mengenai Hak Asasi Manusia (ECHR). Menurut ECHR, pembatasan hak dapat berlaku pada saat perang atau keadaan darurat publik lainnya yang mengancam kehidupan bangsa. Instrumen hukum yang lebih baru biasanya tidak mengacu pada perang tetapi berisi referensi serupa untuk keadaan darurat yang mengancam publik. ICCPR mengacu pada "keadaan darurat publik yang mengancam kehidupan bangsa ...", ${ }^{25}$ sementara ACHR menyebutkan "waktu perang, bahaya publik, atau keadaan darurat lainnya yang mengancam kemerdekaan atau keamanan suatu Negara". ${ }^{26}$

Di sisi lain, Pengadilan Hak Asasi Manusia Eropa mendefinisikan "keadaan darurat publik yang mengancam kehidupan bangsa sebagai situasi krisis atau darurat yang luar biasa yang mempengaruhi seluruh populasi dan merupakan ancaman bagi kehidupan terorganisir komunitas di mana Negara disusun". ${ }^{27}$ Pengadilan memutuskan bahwa keadaan darurat harus 'aktual atau segera'. ${ }^{28}$

derogation to human rights," Journal of Law and the Biosciences (n.d.): 1-15, https://rm.coe. int/09000016809cf9a2.

24 Pasal 2 ECHR, Pasal 4 ACHR, Pasal 6 ICCPR.

25 Pasal ayat 1 ICCPR.

26 Pasal 27 ayat 1 ACHR.

27 T H E Lawless Case, "WORLD LAW-THE LAWLESS CASE" 1962: 249 (1961), https://scholarship.law.duke. edu/cgi/viewcontent.cgi?referer=https://www.google. $\mathrm{com} / \&$ httpsredir $=1 \&$ article $=1804 \&$ context $=\mathrm{dlj}$.

28 European Commission Of Human Rights, "Denmark V Greece 1969," last modified 1969, diakses Agustus 3, 2021, https://www.echr.coe.int/Documents/Denmark Norway_Sweden_Netherlands_v_Greece_I.pdf. 
Kriteria sifat darurat yang akan segera terjadi adalah sangat penting dalam konteks pandemi, karena memungkinkan negara untuk segera mengantisipasi dengan mengambil langkahlangkah pembatasan dini untuk menghindari pembatasan yang lebih parah di kemudian hari. Tidak ada keraguan lagi bahwa krisis Covid-19 sesuai dengan kriteria tersebut, dengan ancaman aktual dan yang akan segera terjadi (tergantung negaranya) terhadap hak semua individu atas kesehatan dan hak untuk hidup. Serta negara biasanya memiliki beberapa keleluasaan mengenai karakterisasi keadaan darurat publik karena mereka berada pada posisi yang efektif untuk menilai risikonya.

Beberapa negara anggota Uni Eropa menyatakan negara mereka dalam keadaan darurat dan mengklaim hak-hak khusus yang diatur dalam Pasal 15 ECHR bahwa negara dibolehkan dalam keadaan darurat untuk membatasi hak-hak tertentu dan harus segera dicabut jika situasinya telah usai. Pada pertengahan Agustus 2020 Albania, Armenia, Estonia, Georgia, Latvia, Makedonia Utara, Moldova, Rumania, San Marino, dan Serbia telah memberi tahu Sekretaris Jenderal Majelis Eropa atas niat mereka untuk mengklaim Pasal 15 ECHR guna menekan penyebaran virus Covid-19 dan Sekarang ini, Albania, Estonia, Latvia, Makedonia Utara, Moldova, Rumania, dan San Marino telah menarik keputusan pengurangan, karena laju penyebaran virus Covid-19 telah menurun. Beberapa negara anggota lainnya memilih untuk tidak menggunakan Pasal 15 ECHR dan konsekuensinya mereka tetap harus mematuhi ketentuan standar ECHR dalam menanggulangi virus Covid-19. ${ }^{29}$

Sementara di Indonesia sendiri sudah menginterpretasikan Covid-19 sebagai "keadaan darurat kesehatan akibat daripada itu Presiden Joko Widodo, pada 31 Maret 2020 telah menetapkan

$29 \quad$ Anja Radjenovic, "Upholding human rights in Europe during the pandemic Derogations under the European Convention of Human," no. September (2020): 12, https://www.europarl.europa.eu/RegData/etudes/ BRIE/2020/652085/EPRS_BRI\%282020\%29652085_ EN.pdf.
Keputusan Presiden (Keppres) No. 11 Tahun 2020 tentang Penetapan Kedaruratan Kesehatan MasyarakatCorona VirusDisease2019 (Covid-19). Sejalan dengan hal tersebut terbit pula Peraturan Pemerintah Pengganti Undang-Undang (Perppu) No. 1 Tahun 2020 tentang Kebijakan Keuangan Negara dan Stabilitas Sistem Keuangan Untuk Penanganan Pandemi Corona Virus Disease 2019 (Covid-19) dan/atau Dalam Rangka Menghadapi Ancaman Yang Membahayakan Perekonomian Nasional dan/atau Stabilitas Sistem Keuangan. Dapat kita lihat dari contoh sebelumnya bahwa, negara secara umum banyak yang tidak siap dalam menghadapi pandemi Covid-19. Sehingga akhirnya banyak negara yang melakukan diskresi untuk tetap memastikan kegiatan pemerintahan negaranya berjalan tetapi tetap menjunjung tinggi Hak Asasi Manusia (HAM).

\section{Hak atas Bergerak Dimasa Pandemi}

Pada hakikatnya setiap negara diwajibkan mematuhi setiap ketentuan hukum internasional yang sudah dibuat berdasarkan prinsip pacta sunt servanda ${ }^{30}$. Di mana ketentuan hukum internasional merupakan undang-undang (hukum) yang mengikat para pihak. Reputasi dan citra suatu negara sangat tergantung atas ketaatannya dalam menjalankan setiap hukum internasional yang sudah menjadi hukum baik melalui proses perjanjian yang membentuk hukum (law making treaty) ataupun kesepakatan kedua belah pihak (treaty contract). ${ }^{31}$

Kegagalan dan ketidakmampuan suatu negara dalam memenuhi kewajiban berdasarkan hukum internasional adalah bentuk pelanggaran hukum internasional dan menyebabkan negara tersebut dipandang tidak memiliki kredibilitas. ${ }^{32}$ Seperti dikemukan oleh Louis Henkin "If diplomacy can maintain a climate of order and provide lawful means for achieving change, these will induce

30 Lihat Konvensi Wina 1969 tentang Perjanjian Internasional

31 Anthony Aust, "Modern Law Treaty Practice" (Cambridge: Cambridge Press, 2002), 404.

32 Damos Dumoli, "Treaties Under Indonesian Law : A comparative Study" (Bandung: RosdaKarya, 2014), 21. 
the acceptance of law and the development of institutions for its observance. Habits of accepting and observing law will, in turn, contribute to international order and stability." ${ }^{33}$ Akibatnya dengan adanya ketidakpatuhan akan kewajiban internasional dapat memengaruhi sistem hukum internasional itu sendiri. Konsekuensinya negaranegara memiliki kepentingan dalam kepatuhan karena ketidakpatuhan dapat mempengaruhi stabilitas hukum internasional secara keseluruhan yang mungkin dapat merugikan mereka.

Kepatuhan dan ketidakpatuhan negara atas pemenuhan HAM akan dinilai dalam institusi internasional dan itu berkorelasi dengan citra suatu negara dimata internasional. Selain itu adanya kepatuhan juga menunjukan komitmen dan dampak perubahan standar penghormatan hak individu yang menjadi harapan dari pengaturan Ham internasional. ${ }^{34}$

Pemenuhan hak asasi manusia menjadi kewajiban bagi negara-negara di dunia, apalagi bagi negara-negara yang sudah meratifikasi instrumen HAM internasional. Tidak hanya itu, bagi negara yang berpondasi demokrasi dan negara hukum maka ciri fundamental yang harus ada adalah jaminan HAM. HAM sendiri dikelompok dalam dua tipe yaitu HAM yang mutlak dan HAM relatif. HAM yang bersifat mutlak, tidak dapat dikurangi dalam pemenuhannya (non- derogable rights). Dikatakan oleh Malcom Shaw "certain rights may not be derogated from in the various human rights instrument even in times of war or other public emergency threatening the nation ${ }^{35}$. Vis versa terdapat hak asasi yang pemenuhannya masih dapat ditoleransi dengan beberapa alasan.

33 Jacob Katz Cogan dan Jacob K Cogan, "Noncompliance and the International Rule of Law Essay Noncompliance and the International Rule of Law," Yale J. Int'l L 31, no. 1991 (2006), http://digitalcommons.law.yale. edu/yjil\%0Ahttp://digitalcommons.law.yale.edu/yjil/ vol31/iss $1 / 4$.

34 Joel P Trachtman, "The Future of International Law, Global Government" (Cambridge: Cambridge Press, 2014), 139.

35 Malcolm Shaw, "International Law, Eight Edition" (Cambridge: Cambridge Press, 2017), 216.
Negara memang mempunyai kewajiban untuk menjunjung tinggi hak asasi manusia, namun negara diizinkan pula untuk membatasi kewajiban hak asasi manusia mereka dengan cara tertentu dan dalam keadaan terbatas. ICCPR mengakui bahwa pembatasan pada hak-hak tertentu dapat dilakukan selama "keadaan darurat publik yang mengancam kehidupan bangsa". Pasal 4 kovenan mengizinkan suatu negara untuk mengambil tindakan yang menyimpang, atau mengurangi dari kewajibannya dengan syarat: (1) jika keadaan darurat secara resmi diumumkan, (2) pembatasan tersebut merupakan upaya terakhir dan (3) jika Tindakan tersebut tidak mengandung diskriminasi semata-mata atas dasar ras, warna kulit, jenis kelamin, bahasa, agama atau asal-usul sosial. Disisi lain pasal tersebut membatasi kemampuan untuk membatasi dengan mencantumkan tujuh hak khusus yang darinya pembatasan tidak diperbolehkan. ${ }^{36}$ Ketika melakukan pembatasan hak-hak, negara diwajibkan untuk memberi tahu Sekretaris Jenderal PBB tentang "ketentuan yang telah dibatasi dan alasannya" untuk pembatasan tersebut. Pemberitahuan selanjutnya juga diperlukan saat pembatasan tersebut berakhir. Sekretaris Jenderal menerbitkan pemberitahuan ini kepada negara anggota lainnya.

Jelas dari laporan berbagai macam berita bahwa banyak negara telah menyatakan keadaan darurat dan mengambil tindakan luar biasa untuk memperlambat penyebaran Covid-19. Namun, sejauh ini hanya sepuluh negara yang telah memberi tahu PBB bahwa mereka telah mengurangi kewajiban ICCPR mereka karena pandemi. ${ }^{37}$ Kewajiban yang dimaksud diatur dalam Pasal 4 ayat 3 ICCPR yang mengatur kewajiban Negara untuk segera melapor ke Sekretaris

36 Adapun 7 hak khusus yang tidak boleh dibatasi tersebut dapat dilihat di Pasal 6,7,8(1-2),11,15,16 dan 18 Kovenan Kebebasan Sipil dan Politik (ICCPR).

37 "Human Rights and COVID-19: Human Rights Obligations of States During the COVID-19 Pandemic - Human Rights Pulse," diakses April 9, 2021, https://www.humanrightspulse. com/mastercontentblog/human-rights-andcovid-19-human-rights-obligations-of-statesduring-the-covid-19-pandemic. 
Jenderal PBB atas klaim mereka terhadap keadaan darurat negaranya disertai dengan alasan mengapa mereka menyatakan tersebut. Tidak satu pun negara yang terkena dampak paling parah, seperti China, Italia, Spanyol, dan Amerika Serikat, telah memberikan pemberitahuan, namun mereka jelas telah mengambil tindakan yang menyimpang dari kewajiban mereka di bawah ICCPR. Dengan tidak memberikan pemberitahuan, negara melanggar kewajiban hak asasi manusia meskipun kebijakan tertentu yang dilakukan dapat diterima secara wajar.

Kuncinya di sini bahwa negara harus melaporkan kepada Sekretaris Jenderal PBB atas alasan mereka menyimpang dari kewajiban mereka yang tercantum didalam ICCPR. Namun, walaupun negara tidak melapor kepada Sekretaris Jenderal PBB. Komite Internasional tetap berhak untuk memantau hukum dan praktik suatu Negara Anggota untuk memenuhi pasal 4 ICCPR oleh karena Negara Anggota secara otomatis terikat dengan ketentuan tersebut dan tidak bergantung pada apakah Negara Anggota tersebut telah menyampaikan pemberitahuan, sehingga jika ada kebijakan dari negara tersebut yang tidak sesuai dan melanggar HAM tetap akan dipertanggung jawabkan terlepas mereka telah melapor atau tidak kepada Sekjen PBB mengenai kebijakan negara mereka dalam keadaan darurat.

\section{Kepatuhan Negara terhadap Regulasi Kesehatan Internasional (IHR 2005)}

Regulasi Kesehatan Internasional (International Health Regulation 2005), selanjutnya disebut IHR 2005, adalah instrumen Hukum Internasional yang mengikat negaranegara di dunia, termasuk anggota Organisasi Kesehatan Dunia (WHO). IHR sendiri mempunyai tujuan untuk membantu komunitas internasional dalam menghadapi penyakit yang mengancam masyarakat dunia termasuk Virus Covid-19. Ketentuan dalam IHR 2005 memberikan perlindungan bagi warga negara anggota dari penyebaran penyakit lintas negara.

Di dalam IHR 2005 memuat ketentuan larangan pembatasan hak untuk bergerak (right to move) sebagai kebijakan yang dapat diambil dalam penanganan penyebaran penyakit lintas negara. Ketentuan tersebut termaktub didalam Pasal 2 IHR 2005. Selengkapnya berbunyi:

"The purpose and scope of these Regulations are to prevent, protect against, control and provide a public health response to the international spread of disease in ways that are commensurate with and restricted to public health risks, and which avoid unnecessary interference with international traffic and trade".

Berdasarkan ketentuan Pasal 2 IHR 2005 diatas bertujuan memberikan panduan dalam menangani penyebaran penyakit lintas negara namun pada frasa terakhir dari ketentuan a quo mengisyaratkan bahwa kebijakan penanganan penyebaran penyakit lintas batas negara sebisa mungkin menghindari penggunaan pembatasan hak untuk bergerak dan pembatasan distribusi perdagangan lintas negara.

Meskipun adanya rambu larangan pembatasan hak untuk bergerak, namun bukan berarti larangan pembatasan hak untuk bergerak bersifat absolut, sebab Pasal 43 IHR 2005 membolehkan negara-negara anggota WHO untuk melakukan pembatasan bergerak lintas negara guna menekan penyebaran suatu penyakit melalui kebijakan tambahan yang bersifat kasuitis (additional measures). Artinya negara dapat saja membatasi pergerakan orang masuk ke negara mereka dengan alasan-alasan tertentu sebagaimana ditetapkan dalam Pasal 43 IHR 2005. Sehingga pembatasan hak untuk bergerak dapat dilakukan sebagai kebijakan tambahan dan wajib memenuhi parameter yang ditetapkan WHO berupa : pertama, adanya bukti ilmiah bahwa kebijakan tersebut dapat menurunkan penyebaran penyakit lintas negara, kedua, tersedianya bukti ilmiah dan relevan dengan upaya penuruan penyebaran penyakit yang dikeluarkan oleh WHO atau organisasi internasional relevan lainnya, ketiga, tersedianya panduan dan saran secara spesifik yang dikeluarkan oleh WHO. 
Sejauh ini total terdapat 194 negara yang menjadi anggota $\mathrm{WHO}$, sebagai negara anggota maka mutatis mutandis terikat dengan aturan Regulasi Kesehatan Internasional (IHR 2005) dan wajib mengikutinya. Indonesia sebagai salah satu negara anggota telah meratifikasi IHR 2005 dan sebagai tindak lanjutnya Pemerintah Indonesia mengeluarkan Undang-Undang Nomor 6 Tahun 2018 tentang Kekarantinaan Kesehatan.

Pada Prakteknya, tertanggal 7 Februari 2020, terdapat 72 dari 194 negara anggota WHO yang diidentifikasi menerapkan pembatasan hak untuk bergerak dengan menutup perbatasan dan arus masuk orang ke negara mereka. Namun Indonesia bukanlah negara yang menerapkan ketentuan Pasal 43 tersebut, dari 72 negara yang menerapkan pembatasan hak untuk bergerak yang diatur dalam Pasal 43 IHR 2005, hanya 23 negara saja (32\%) yang melaporkan kebijakan pembatasan hak untuk bergerak tersebut secara resmi kepada WHO. Baru tertanggal 9 Maret 2020, bertambah menjadi 45 negara anggota yang memberikan alasan bahwa pembatasan hak atas bergerak yang dilakukan adalah demi keselamatan kesehatan masyarakat kepada WHO. Hal ini menunjukkan bahwa banyak negara tidak mematuhi ketentuan dalam Pasal 43 IHR. ${ }^{38}$ Padahal kebijakan pembatasan hak atas bergerak yang dilakukan dalam penanganan penyebaran Covid-19 tersebut berpotensi melanggar hak asasi manusia.

Padahal WHO telah menegaskan bahwa ketiadaan manfaat pembatasan hak untuk bergerak akan berakibat kebijakan tersebut bertentangan dengan ketentuan IHR 2005 itu sendiri yang mensyaratkan harus ada data ilmiah yang mendukung efektiftas kebijakan tambahan berupa pembatasan hak atas bergerak itu. ${ }^{39}$ Sebab sejatinya, WHO tidak menyarankan

38 Barbara von Tigerstrom dan Kumanan Wilson, "COVID-19 travel restrictions and the International Health Regulations (2005)," BMJ Global Health 5, no. 5 (Mei 17, 2020): 2629, diakses Juli 30, 2021, https:// www.ncbi.nlm.nih.gov/pmc/articles/PMC7237384/.

39 Switzerland, "Revision of the International Health Regulations Comments by the Swiss Government ," last modified 2004, diakses Agustus 3, 2021, https:// www.who.int/ihr/revisionprocess/swissIHR.pdf?ua=1 . adanya pembatasan hak untuk bergerak dalam penanganan penyakit lintas negara sebagaimana disebut dalam Pasal 2 IHR 2005. Oleh karena itu, masing-masing negara memiliki kewajiban untuk mematuhi ketentuan, pedoman dan rekomendasi yang dibuat oleh WHO. ketidakpatuhan untuk melaporkan kebijakan pembatasan hak atas bergerak merupakan pelanggaran hukum internasional dan menghambat kinerja WHO dalam penanganan penyakit lintas negara. ${ }^{40}$

\section{E. Instrumen Hukum Penanganan Penyebaran Virus Covid-19 di Indonesia}

Hans Kelsen dalam bukunya General Theory of Law and State (1973) menjelaskan tentang struktur hierarki norma hukum, berkaitan dengan posisi UUD 1945 sebagai norma tertinggi di Indonesia, maka sesungguhnya tidak bisa dilepaskan dari fungsinya sebagai konstitusi negara. Dimana konstitusi memuat norma-norma yang bersifat umum yang kemudian dapat di intrepretasikan dalam berbagai kebijakan hukum dibawahnnya. ${ }^{41}$

Sri Soemantri Martosoewignjo mengatakan inti dari konstitusi adalah adanya pembatasan kekuasaan yang mencakup tiga hal yaitu (1) jaminan hak asasi manusia, (2) susunan ketatanegaraan yang mendasar, (3) aturan tugas dan wewenang dalam negara. ${ }^{42}$ Karena hak asasi manusia merupakan salah satu materi muatan yang ada didalam konstitusi khususnya konstitusi modern maka pemenuhan atas jaminan HAM tersebut perlu disoroti. Posisi UndangUndang Dasar sebagai hukum dasar inilah yang memberikan konsekuensi hukum bahwa setiap materi yang diatur dalam peraturan perundangundangan yang berada dibawahnya tidak boleh bertentangan dengan materi dalam UUD 1945. Hal

40 WHO, "Coronavirus disease 2019 (COVID-19) Situation Report - 39," last modified Februari 28, 2020, diakses Juli30,2021, https://www.who.int/docs/defaultsource/coronaviruse/situation-reports/20200228sitrep-39-covid-19.pdf?sfvrsn=5bbf3e7d 4 .

41 Aziz Syamsyuddin, "Proses dan Teknik Penyusunan Undang-Undang,” Edisi 2. (Jakarta: Sinar Grafika, 2013), 32.

42 Sri Soemantri, "Prosedur dan Sistem Perubahan Konstitusi" (Bandung: Alumni, 2006), 23. 
ini berkaitan dengan salah satu fungsi konstitusi dalam suatu negara sebagaimana dikemukan oleh Hence Van Masrseveen, sebagai a politico legal document, yaitu dokumen politik dan hukum suatu negara yang berfungsi sebagai alat untuk membentuk sistem politik dan sistem hukum suatu negara.

Sebelum Perubahan Undang-Undang Dasar 1945, Nuansa perlindungan hak asasi manusia tidak menjadi materi yang muncul banyak sebagai materi muatan konstitusi di awal kemerdekaan. Hal demikian terjadi karena muncul perdebatan antara para pendiri bangsa (founding fathers) tentang gagasan HAM di dalam konstitusi. ${ }^{43}$ Perdebatan ini berujung dengan nuansa perlindungan HAM yang tidak muncul secara implisit dalam konstitusi. Hal demikian dikarenakan, pemikiran paham integralistik (kekeluargaan) yang diutarakan oleh Soepomo. ${ }^{44}$

Pemikiran Soepomo tersebut dibantah oleh Hatta. Pada prinsipnya Hatta, sama-sama menentang dan menolak negara berdasarkan paham individualisme-liberal sebagaimana Soepomo, dan setuju dengan konsep negara integralistik (kekeluargaan) yang diusulkan. Meskipun demikian, menurut Hatta jaminan hak asasi manusia tetaplah dibutuhkan dalam konstitusi Indonesia merdeka. Alasannya adalah untuk mencegah negara berdasarkan kekuasaan

43 Para pendiri bangsa terbagi menjadi 2 (dua) kelompok yaitu kelompok yang menolak pencantuman pasal HAM dalam konstitusi Indonesia (Sukarno \& Soepomo) dan kelompok yang menginginkan jaminan HAM muncul di dalam materi muatan konstitusi Indonesia seperti deklarasi HAM yang dimiliki oleh Perancis (Muhammad Hatta \& Yamin).

44 Ia sebagai salah satu Begawan hukum Indonesia saat itu berkeyakinan seyogyanya dalam negara Indonesia merdeka yang ingin dibentuk adalah negara berdasarkan paham integralistik (kekeluargaan) sehingga tidak diperlukan adanya jaminan ham diatur didalam konstitusi Indonesia merdeka. Sebab dalam konsep negara integralistik hubungan negara dan warga negara diibaratkan hubungan ayah dan anak. Sehingga tidak mungkin kemudian ayah (negara) membuat aturan yang melanggar hak asasi anaknya (warga negara). Memasukan pengaturan HAM dipandang menggeser paham integralistik menjadi negara berdasarkan paham individualisme-liberal (machtstaat). Bahkan pemikiran Hatta ini didukung pula oleh M Yamin yang justru menginginkan Pasal tentang HAM tidak hanya dirumuskan dalam satu Pasal saja di dalam konstitusi tetapi dalam berbagai pasal atau lebih dari satu pasal. ${ }^{45}$

Pasca amandemen Undang-Undang Dasar 1945, Konstitusi Indonesia memiliki nuansa perlindungan HAM yang lebih rimbun dibandingkan dengan konstitusi di awal kemerdekaan UUD NRI 1945 bahkan pada tahapan perubahan Undang-Undang Dasar 1945 yang berlangsung dalam kurun 4 tahun mulai 1999, 2000, 2001, dan 2002 itu perubahan konstitusi berlangsung sangat ekstrim dan radikal. Menurut Jimly Asshiddiqie, UUD 1945 hasil perubahan mengalami perubahan yang luar biasa yaitu 300 $\%$ berubah dari aslinya. Yaitu yang awalnya terdiri atas: pembukaan (4 alinea), 16 Bab, 37 Pasal, 49 ayat, 4 Pasal aturan peralihan dan 2 ayat aturan tambahan serta penjelasan berubah menjadi terdiri atas: pembukaan (4 alinea), 21 Bab, 73 Pasal, 170 ayat, 3 pasal aturan peralihan dan 2 pasal aturan tambahan. Bahkan sebagian ahli beranggapan bahwa yang terjadi bukanlah perubahan atau amandemen konstitusi melainkan lahirnya konstitusi baru. ${ }^{46}$

Kelahiran Pasal HAM mendapatkan porsi yang cukup banyak bahkan terdapat bab khusus yang lahir dan mengatur mengenai hak asasi manusia yaitu Bab XA yang terdiri atas Pasal 28 huruf A hingga J. Pengaturan perlindungan HAM dalam konstitusi Indonesia ini tentunya memberikan sinyal komitmen bangsa Indonesia untuk memberikan perlindungan dan jaminan pemenuhan HAM bagi seluruh rakyatnya sebagai salah satu syarat negara hukum (rule of law). Bahkan kesungguhan bangsa Indonesia dalam memberikan jaminan HAM tersebut diikuti dengan langkah meratifikasi sejumlah konvensi internasional yang mengatur tentang HAM.

45 Jimly Asshiddiqqie, "Pokok-Pokok Hukum Tata Negara Indonesia Pasca Reformasi” (Jakarta: Jakarta: PT Bhuana Ilmu Populer, 2007), 629-630.

46 Jimly Asshiddiqqie, "Komentar atas Perubahan PasalPasal Undang-Undang Dasar 1945" (Jakarta: Rajawali Press, 2008), 52. 
Indonesia dikatakan sebagai negara yang paling besar progresnya dalam meratifikasi konvensi internasional berkaitan dengan HAM di kawasan Asia Tenggara. ${ }^{47}$ Kebangkitan akan kesadaran jaminan perlindungan HAM tidak terlepas dari sejarah ketatanegaraan yang mengalami kepemimpinan yang otoriter dibawah kekuasaan Presiden Soeharto sehingga dalam perubahan konstitusi memasukan berbagai Pasal HAM tersebut. ${ }^{48}$

Setidaknya, di dalam UUD NRI 1945 perubahan dapat ditemukan sejumlah pasal yang memberikan jaminan Kesehatan seperti Pasal 28 A tentang hak untuk hidup, Pasal 28 E ayat (1) hak untuk memilih tempat tinggal artinya berhubungan dengan kebebasan berpindah dari satu tempat ke tempat yang lain baik dalam maupun luar negeri, Pasal $28 \mathrm{H}$ ayat (1) tentang hak atas Kesehatan, lingkungan hidup yang baik dan pelayanan Kesehatan. Dan hak asasi diatas Sebagian tergolong dalam hak yang tidak dapat dikurangi pemenuhannya sesuai dengan ketentuan Pasal 28 I ayat (1) UUD 1945 yaitu hak untuk hidup (Pasal 28A), namun selain hak atas hidup tersebut tergolong sebagai hak yang dapat saja pemenuhannya dikurangin (non-derogable rights) berdasarkan ketentuan Pasal $28 \mathrm{~J}$ ayat (1) juncto Pasal 28 J ayat (2) UUD 1945 atas dasar pertimbangan keamanan dan ketertiban umum. Oleh karenanya secara konstitusional pembatasan larangan masuk dan perjalanan memiliki landasan konstitusi dalam pemberlakuannya. Apalagi dalam keadaan ihwal kegentingan memaksa UUD 1945 memberikan ruang kebijakan hukum darurat bagi presiden sebagaimana dijamin dalam Pasal 22 dan kemampuan untuk menyatakan negara dalam keadaan bahaya sebagaimana diatur dalam Pasal 12 jika dibutuhkan upaya penanganan keadaan darurat yang ekstra luar biasa.

47 Azkar Ahsinin et al., "Kesenjangan dalam Komitmen dan Implementasi: Mengurai Hambatan Birokratik dalam Penegakan HAM di Indonesia | Perpustakaan ELSAM," last modified 2017, diakses Agustus 3, 2021, http://perpustakaan.elsam.or.id/index.php?p=show_de tail\&id=15254\&keywords=kesenjangan.

48 Denny Indrayana, "Indonesian Constitutional Reform, 1999-2002 : An Evaluation of Constitution-Making in Transition" (Jakarta: Kompas Press, 2008), 19.
Penyebaran wabah Covid-19 direspon agak terlambat oleh Pemerintah Indonesia, di mana pada awal isu penyebaran Covid-19 awalnya sudah masif terjadi di Wuhan-China, Pemerintah Indonesia belum merespon secara responsif dan cepat pada saat itu karena Covid-19 merupakan jenis simpton dan penyakit baru dalam dunia kesehatan dan kebijakan hukum di banyak negara termasuk di Indonesia belum mampu memitigasi hal tersebut sehingga saat setelah itu pemerintah baru menanggapi secara responsif mengenai kasus penyebaran Covid-19 dengan mengeluarkan sejumlah ketentuan hukum dalam hal ihwal kegentingan yang memaksa seperti peraturan pemerintah pengganti undang-undang (Perppu) Nomor 1 Tahun 2020, Peraturan Pemerintah Nomor 21 Tahun 2020 tentang pembatasan sosial berskala besar (PSBB), Keputusan Presiden Nomor 11 Tahun 2020 tentang penetapan kedaruratan kesehatan masyarakat Covid-19, Peraturan Menteri Kesehatan Nomor 9 Tahun 2020 tentang Pedoman Pembatasan Sosial Berskala Besar dalam rangka percepatan penanganan Covid-19 dll.

\section{Undang-Undang Nomor 6 Tahun 2018 tentang Kekarantinaan Kesehatan}

Disebutkan pada bagian menimbang poin c bahwa Undang-Undang Nomor 6 Tahun 2018 tentang Kekarantinaan Kesehatan adalah UndangUndang yang lahir sebagai bentuk komitmen Indonesia melakukan upaya untuk mencegah kedaruratan Kesehatan dan komitmen Indonesia yang telah meratifikasi regulasi international di bidang kesehatan. Dalam UU a quo memberikan definisi yang berbeda mengenai karantina wilayah dan pembatasan sosial berskala besar (PSBB). Dimana isu karantina wilayah dan PSBB ini sempat menjadi debat/diskursus pada awal Indonesia merespon isu penyebaran Covid-19 diawal tahun 2020 yang lalu.

Definisi dari karantina wilayah (Pasal 1 angka 10) menyebutkan pembatasan penduduk dalam suatu wilayah termasuk wilayah pintu masuk berserta isinya yang diduga terinfeksi penyakit dan/atau terkontaminasi sedemikian rupa untuk 
mencegah kemungkinan penyebaran penyakit atau kontaminasi. Sedangkan pembatasan sosial berskala besar (Pasal 1 angka 11) diartikan pembatasan kegiatan tertentu penduduk dalam suatu wilayah yang diduga terinfeksi penyakit dan/atau terkontaminasi sedemikian rupa untuk mencegah kemungkinan penyebaran penyakit atau kontaminasi.

Dengan kata lain, karantina wilayah diartikan dengan adanya pembatasan masuk/ keluar orang dari wilayah yang dianggap beresiko tinggi menjadi sumber penularan virus Covid-19 sedangan pembatasan sosial berskala besar lebih menekan adanya pembatasan pada kegiatan atau aktivitas masyarakat semata yang patut diduga menjadi sumber penyebaran virus untuk interval waktu tertentu.

Untuk penanganan secara domestik penyebaran dari Covid-19 ini, Pemerintah memilih mengambil kebijakan pembatasan sosial berskala besar dibandingkan menerapkan karantina wilayah. Pilihan ini sempat dikaitkan dengan kemampuan Pemerintah pada saat itu untuk melaksanakan kekarantinaan wilayah. Dalam Pasal 55 Ayat (1) UU Kekarantinaan menyebutkan adanya kewajiban negara manakala menetapkan status karantina wilayah yaitu: selama dalam karantina wilayah, kebutuhan dasar orang dan makanan hewan ternak yang berada di wilayah karantina menjadi tanggung jawab pemerintah pusat. Selanjutnya ayat (2) menjelaskan tanggung jawab pemerintah pusat tersebut dilakukan dengan pelibatan pemerintah daerah dan pihak yang terkait.

Diduga untuk menghindari kewajiban sebagaimana disebut Pasal 55 ayat (1) ini Pemerintah kemudian menggunakan kebijakan Pembatasan Sosial Berskala Besar. Sementara beberapa kebijakan yang diambil dalam penanganan Covid-19 tidak hanya tindakantindakan sebagaimana bentuk dari Pembatasan Sosial Berskala Besar yaitu a) peliburan sekolah dan tempat kerja;, b) pembatasan kegiatan keagamaan; dan/atau pembatasan kegiatan di tempat atau fasilitas umum (Pasal 59 ayat (3)
UU a quo) tetapi juga melakukan penyekatan untuk memasukin beberapa wilayah tertentu di Indonesia layaknya kegiatan karantina wilayah.

Dalam pelaksanaan karantina wilayah terdapat sejumlah asas yang perlu diperhatikan oleh Pemerintah (Pasal 2 UU Kekarantinaan Wilayah), yaitu sebagai berikut: a) perikemanusiaan b) manfaat, c) perlindungan d) keadilan f) non-diskriminatif; g) kepentingan umum h) keterpaduan i) kesadaran hukum dan j) kedaulatan negara. Pada intinya asas ini meletakkan fondasi pelaksanaan kebijakan kekarantinaan kesehatan dalam menangani isu kesehatan yang sensitif dan berbahaya. Prinsip-prinsip tersebut menjadi lampu kuning yakni alarm bagi pembuat kebijakan untuk memperhatikan jaminan hak asasi manusia dan dampaknya. Bahkan kekarantinaan kesehatan secara tegas menyebutkan bahwa kekarantinaan dapat dilakukan demi kepentingan nasional dan itu merupakan bagian dari kedaulatan negara. Selain itu prinsip non-diskriminasi dalam pelaksanaan dan memberikan perlindungan kepada kepentingan hidup rakyat.

\section{Undang-Undang Nomor 39 Tahun 1999 tentang Hak Asasi Manusia}

Undang-Undang Nomor 39 Tahun 1999 tentang Hak Asasi Manusia lahir sebagai bagian dari produk reformasi 1998 yang haus akan jaminan HAM. UU a quo sebagai bentuk jaminan dan kepastian hukum serta mencegah pelanggaran hak asasi manusia baik dapat dilakukan oleh pemerintah kepada warga negarannya ataupun sesama warga negara. Pasal 1 angka 6 mendefinisikan pelanggaran hak asasi manusia sebagai setiap perbuatan seseorang atau kelompok orang termasuk aparat negara baik disengaja maupun tidak disengaja atau kelalaian, membatasi, dan atau mencabut hak asasi manusia seseorang atau kelompok orang yang dijamin oleh undang-undang ini, dan tidak mendapatkan, atau dikhawatirkan tidak akan memperoleh penyelesaian hukum yang adil dan benar berdasarkan mekanisme hukum yang berlaku. Undang-Undang a quo sejatinya juga memberikan 
perlindungan kepada setiap orang untuk bebas bergerak, berpindah dan bertempat tinggal dalam wilayah negara Republik Indonesia, termasuk hak untuk meninggalkan dan masuk kembali ke wilayah negara Republik Indonesia, sesuai dengan ketentuan peraturan perundang-undangan (Pasal 27 ayat (1) dan (2) UU Ham)

Klausul terakhir yang menyebutkan "sesuai dengan ketentuan peraturan perundang-undangan" sejatinya adalah norma yang memberikan ruang kepada negara untuk membatasi hak berpindah orang dalam wilayah Indonesia. Sehingga penerapan pembatasan masuk dan pembatasan perjalanan menjadi memiliki basis hukum dalam pelaksanaannya. Lebih lanjut pembatasan dan larangan tersebut juga diatur dalam Bab VI tentang Pembatasan dan Larangan Pasal 73 berbunyi " hak dan kebebasan yang diatur dalam undang-undang ini hanya dapat dibatasi oleh dan berdasarkan undang-undang, semata-mata untuk menjamin pengakuan dan penghormatan terhadap hak asasi manusia serta kebebasan dasar lain, kesusilaan, ketertiban umum dan kepentingan bangsa" dengan kata lain, pembatasan hak berpindah/ bergerak dapat dilakukan oleh Pemerintah dengan membentuk aturan selevel UU saja.

\section{Undang-Undang Nomor 24 Tahun 2007 tentang Penanggulangan Bencana}

Undang-Undang Nomor 24 Tahun 2007 tentang Penanggulangan Bencana adalah instrumen hukum yang digunakan untuk menghadapi bencana yang terjadi di Indonesia. Berdasarkan jenisnya, penyebaran Covid-19 yang terjadi di Indonesia dikategorikan sebagai bencana non alam. Bencana non alam adalah bencana yang diakibatkan oleh peristiwa atau serangkaian peristiwa non alam yang diantara lain berupa gagal teknologi, gagal moderenisasi, epidemi dan wabah penyakit (pasal 1 angka 3). Dan untuk menanggulanginya maka terdapat sejumlah prinsip yang perlu diperhatikan Pasal 3 ayat (2). Prinsip itu terdiri atas: a) cepat dan tepat; b)prioritas; c) koordinasi; $d$ ) keterpaduan; e)berdaya guna dan $\mathrm{f}$ ) berhasil guna; $g$ ) transparansi; $h$ )akuntabilitas; i) non-diskriminasi; k) non proletisi
UU Penanggulangan Bencana adalah salah satu undang-undang yang dirujuk oleh Pemerintah Indonesia pada saat mengatasi Pandemi sebagai Bencana Non-alam. Sehingga pemberlakuan sejumlah kebijakan berkaitan dengan penanganan penyebaran Covid-19 harus sejalan dengan prinsip dalam UU ini. Di antaranya, koordinasi lintas kelembagaan menjadi syarat yang perlu dipatuhi, keterpaduan tiap kebijakan, transparansi dalam pelaporan perkembangan dan akuntabilitas pemerintah dalam menangani pandemic ini. Selain itu kebijakan yang dibuat juga tidak boleh diskriminasi.

\section{Undang-Undang Nomor 6 Tahun 2011 tentang Keimigrasian}

Undang-Undang Nomor 6 Tahun 2011 tentang Keimigrasian tidak mengatur secara spesifik larangan atau pembatasan perjalanan khususnya untuk penanganan Covid-19. Hanya saja dalam UU a quo mengatur mengenai pencegahan dan penangkalan orang untuk keluar dan masuk Indonesia dengan alasan keimigrasian. Yang dimaksud dengan alasan keimigrasian adalah alasan yang berkaitan dengan kedaulatan dan keselamatan rakyat dan negara. Sebagaimana didefinisikan dalam Pasal 1 angka 1, angka 28 juncto angka $29 \mathrm{UU}$ a quo.

Selain itu disebutkan juga dalam Pasal 13 ayat (1) huruf f, bahwa Pejabat Imigrasi menolak orang asing masuk wilayah Indonesia dalam hal orang asing tersebut menderita penyakit menular yang membahayakan. Lebih lanjut Pasal 75 ayat (1) mengatakan bahwa Pejabat Imigrasi dapat melakukan tindakan administratif keimigrasian terhadap WNA yang melakukan kegiatan berbahaya dan patut diduga membahayakan keamanan dan ketertiban umum atau tidak menghormati atau tidak menaati peraturan perundang-undangan.

Artinya dalam kondisi penanganan penyebaran Covid-19 yang merupakan ancaman yang membahayakan tindakan pembatasan hak untuk bergerak dimungkinkan. Lebih dalam lagi Pasal 75 ayat (2) huruf c menyebutkan larangan untuk berada di satu atau beberapa tempat 
tertentu di wilayah Indonesia. Artinya atas dasar peraturan perundang-undang seseorang dapat saja dilarang untuk memasuki wilayah Indonesia termasuk larangan masuk yang disebabkan adanya penyebaran Covid-19.

5. Peraturan Menteri Hukum dan Hak Asasi Manusia Nomor 11 Tahun 2020 Tentang Larangan Sementara Orang Asing Masuk Wilayah Negara Republik Indonesia

Dalam ketentuan PerMenKumHam Nomor 11 Tahun 2020 ini menyebutkan tentang ada larangan sementara orang asing untuk memasuki/transit di wilayah Indonesia sebagaimana disebutkan di dalam Pasal 2 Peraturan a quo. Meski ada pembatasan sementara bagi orang asing tetapi pembatasan tersebut tidak berlaku secara umum. Pelarangan sebagaimana dimaksud dalam Pasal 2 PerMenKumHam a quo mengecualikan bagi beberapa kelompok orang tertentu sebagaimana disebut dalam Pasal 3 ayat (1) yaitu a)orang Asing pemegang Izin Tinggal Terbatas dan Izin Tinggal Tetap; b)orang Asing pemegang Visa Diplomatik dan Visa Dinas; c)orang Asing pemegang Izin Tinggal Diplomatik dan Izin Tinggal Dinas; d) tenaga bantuan dan dukungan medis, pangan dan alasan kemanusiaan; e)awak alat angkut; dan Orang Asing yang akan bekerja pada proyek strategis nasional.

Orang Asing dapat masuk wilayah Indonesia setelah memenuhi persyaratan: a)surat keterangan sehat dalam bahasa Inggris dari otoritas kesehatan di masing-masing negara; b)telah berada 14 (empat belas) hari di wilayah/negara yang bebas virus Covid-19; c)Pernyataan bersedia masuk karantina selama 14 (empat belas) hari yang dilaksanakan oleh Pemerintah Republik Indonesia.

Sedangkan bagi WNA pemegang izin tinggal kunjungan, pemegang izin tinggal terbatas dan izin tinggal tetap yang akan berakhir dan/ atau tidak dapat diperpanjang, dilakukan penangguhan sementara untuk tetapi tinggal di Indonesia. (Pasal 4 dan Pasal 5 PerMenkumHam a quo)
6. Surat Edaran Nomor 8 Tahun 2021 tentang Protokol Kesehatan Perjalanan Internasional Pada Masa Pandemi Corona Virus Disease 2019 (Covid-19)

Dalam surat edaran ini diatur mengenai protokol kesehatan perjalanan internasional ditengah pandemik. Pertama, Pelaku perjalanan internasional yang berstatus warga negara Indonesia (WNI) dari luar negeri diijinkan memasukan Indonesia dengan tetap mengikuti protocol kesehatan ketat sebagaimana ditetapkan oleh pemerintah. Kedua, Larangan memasuki wilayah Indonesia baik secara langsung maupun transit di negara asing tetap diberlakukan bagi pelaku perjalanan internasional yang berstatus warga negara asing (WNA) kecuali yang memenuhi kriteria sebagai berikut: a) sesuai ketentuan dalam Permenkumham Nomor 26 Tahun 2020 tentang visa dan izin dalam masa adaptasi kebiasaan baru; b)sesuai skema perjanjian bilateral travel corridor arrangement (TCA) dan/atau; c)mendapatkan pertimbangan/izin khusus secara tertulis dari kementerian/ Lembaga.

Berbagai instrumen hukum yang ada di Indonesia baik berupa peraturan perundangundangan yang lahir sebelum maupun pada saat Covid-19 hadir adalah satu kesatuan upaya dalam memenuhi hak asasi manusia ditengah wabah pandemi korona. Meski tidak dapat dipungkiri bahwa peraturan-peraturan ini tidak akan efektif menekan angka penyebaran virus Covid-19 manakala tidak diikuti dengan ketegasan penegakan hukum penanganan virus Covid-19 dan kesadaran publik untuk mematuhi setiap peraturan yang telah dibuat oleh Pemerintah.

\section{Pelaksanaan Peraturan Penanganan Covid-19 di Indonesia}

Sebagaimana dinukilkan oleh Lawrence W Friedmen bahwa kekuatan dalam sistem hukum berada pada tiga elemen. Pertama, keberadaan substansi hukum (legal substance) yang memadai dan disusun berdasarkan keadilan. Artinya peraturan dibuat secara baik dan tegas dengan mempertimbangkan kebermanfaaatan bagi kemaslahatan rakyat (the greatest happiness 
for the greatest numbers). Kedua, adanya sistem dan mekanisme mitigasi dan penegak hukum (legal structure) yang profesional dan mumpuni baik secara kualitas dan kuantitas untuk menegakan hukum dan aturan selama penanganan Covid-19. Pemerintah harus mengukur kesiapan, proporsionalitas dan kemampuan sistem yang ada dalam menangani dan menegakan hukum yang telah dibuat. Ketiga, kesadaran berperilaku dan kepedulian sosial publik untuk memahami bahwa wabah korona tidak dapat diselesaikan sendiri namun dibutuhkan Kerjasama semua elemen masyarakat (legal culture).

Melihat kondisi saat ini, maka penanganan Covid-19 di Indonesia memiliki beberapa catatan masalah dimasing-masing elemen sebagaimana diuraikan diatas. Pertama, dari segi pengaturan perundang-undangan yang hanya mengedepankan pelarangan hak untuk bergerak (right to move) melalui kebijakan pembatasan sosial berskala besar (PSBB) namun seyogyanya kebijakan PSBB harus tetap diikuti dengan kompensasi atas akibat pelarangan tersebut seperti adanya pemenuhan hajat masyarakat. Walaupun dapat dipahami di dalam kebijakan PSBB memang tidak membebankan tanggung jawab kepada Pemerintah untuk melakukan pemenuhan kebutuhan dasar bagi kelompok terdampak. Sejatinya usaha membantu meringankan beban ekonomi dan sosial yang ditanggung oleh masyarakat telah diupayakan oleh Pemerintah melalui bantuan sosial dan berbagai insentif, namun sepertinya kebijakan tersebut belum efektif dan efesien mengurangi resiko dalam kebijakan PSBB.

Kedua yaitu kepatuhan publik atas peraturan yang sudah dibuat karena masyarakat dihadapkan dengan isu Kesehatan publik vis a vis isu ekonomi untuk melanjutkan kehidupan. Kepatuhan publik untuk menerapkan anjuran dan aturan pemerintah semakin melemah dan berkurang dikarenakan dihadapkan pada dilema kesehatan vs kebutuhan ekonomi. Ketiga, ketersedian penegak hukum dan pemahaman penegak hukum dalam menjalankan peraturan perundang-undangan berkaitan dengan penanganan Covid-19. Tidak jarang ketidaksiapan dan kekurangan pemahaman aparatur dalam melakukan penegakan hukum dalam penanganan penyebaran Covid-19 berujung kepada konflik horizontal yang terjadi dilapangan. Keempat, pada pembuat kebijakan (antar kementerian) isu ketidakkonsistennya kebijakan pun terjadi, seperti adanya kelonggaran bagi beberapa WNA untuk dapat masuk ke wilayah Indonesia, atau kebijakan yang blunder dalam mencegah penyebaran seperti yang terjadi pada musim perayaan hari besar keagamaan (mudik) dan pembukaan fasilitas umum. Sehingga tujuan dari adanya pembatasan hak untuk bergerak menjadi tidak efektif dalam upaya untuk menurunkan kasus penyebaran Covid-19 di Indonesia.

\section{KESIMPULAN}

Virus Korona adalah masalah kesehatan dan pandemik yang dihadapi oleh semua negara di dunia. Penanganan penyebaran korona dilakukan oleh setiap negara dengan menerapkan pembatasan hak untuk bergerak (freedom of movement). Pembatasan hak untuk bergerak dan larangan/pembatasan perjalanan adalah salah satu kebijakan yang diterapkan dengan tujuan menurunkan angka penularan virus. Sebagaimana diketahui, hak untuk bergerak merupakan salah satu hak asasi manusia yang bersifat personal yang dijamin dalam berbagai instrumen hukum hak asasi manusia internasional. Dalam perspektif hukum internasional, negara dibolehkan untuk melakukan pembatasan dan mengurangi kewajiban pemenuhan hak asasi manusia termasuk pembatasan hak untuk begerak. Adapun beberapa instrumen hukum internasional yang memberikan lampu hijau pembatasan hak untuk bergerak adalah Konvensi Uni Eropa tentang Hak Asasi Manusia (ECHR), Konvensi Amerika tentang Hak Asasi Manusia (ACHR), Konvenan Internasional tentang Hak Sipil dan Politik (ICCPR) dan Regulasi Kesehatan Internasional (IHR) yang dikeluarkan oleh WHO.

Keseluruhan instrumen hukum internasional tersebut memberikan kewenangan kepada negara untuk mengambil tindakan pembatasan hak 
untuk bergerak dan larangan perjalanan dalam menghadapi keadaan darurat (state emergency), baik darurat kesehatan maupun darurat sosial. Di Indonesia, kebijakan pembatasan hak untuk bergerak juga diterapkan sejalan dengan penanganan penyebaran Covid-19, diantaranya diatur dalam sejumlah peraturan perundangundangan baik yang sudah ada sebelum Covid-19 maupun yang dibentuk khusus dalam penanganan Covid-19 seperti Undang-Undang Nomor 6 Tahun 2018 tentang Kekarantinaan Kesehatan, Undang-Undang Nomor 39 Tahun 1999 tentang Hak Asasi Manusia, Undang-Undang Nomor 24 Tahun 2007 tentang Penanggulangan Bencana, PerMenKumHAM Nomor 26 Tahun 2020 tentang Visa dan Izin Tinggal Dalam Masa Adaptasi Kebiasaan Baru dan dalam bentuk Surat Edaran Nomor 8 Tahun 2021 tentang Protokol Kesehatan Perjalanan Internasional Pada Masa Pandemi Corona Virus Diseasea 2019 (Covid-19).

\section{SARAN}

Adapun saran Penulis adalah sebagai berikut. Pertama, sejumlah instrumen hukum internasional memberikan kewenangan bagi negara untuk melakukan pembatasan pemenuhan hak asasi manusia sebagaimana dijamin di dalam instrument hukum hak asasi manusia. Meskipun terdapat kewenangan pembatasan, hukum internasional juga memberikan ramburambu dalam pengambilan kebijakan pembatasan tersebut yaitu hanya dapat dilakukan dalam keadaan darurat (emergency), tidak untuk masa waktu yang terlalu lama, dan tidak dilakukan secara diskriminatif. Oleh karena itu, masingmasing negara yang melakukan pembatasan kebebasan bergerak (freedom of movement) harus melakukan dengan sangat hati-hati dan diikuti dengan pertimbangan serta analisa resiko kebijakan secara arif. Tidak hanya itu, kebijakan pembatasan juga harus dilakukan secara adil dan tegas tanpa mendiskriminasi negara-negara tertentu.
Kedua, Indonesia sebagai negara demokrasi yang berlandaskan kedaulatan rakyat, yang identik dengan mengedepankan kepentingan dan keselamatan rakyat (salus populi suprema lex) harus melakukan pembatasan-pembatasan hak untuk bergerak bagi WNA maupun WNI dengan sangat hati-hati, penuh pertimbangan, dan berkeadilan tanpa diskriminasi. Selain itu, Pemerintah Indonesia harus mendasarkan kebijakan pembatasan hak untuk bergerak (right to move) berdasarkan prinsip keadilan seperti yang diutarakan oleh John Rawl yaitu "Maximin" (maximum minimorum) yaitu menimbang manfaat dan mudarat dari kebijakan yang dbuat. Kebijakan pembatasan yang dibuat harus seimbang dan mengakomodasi keadaan faktual masyarakat yang beragam. Pembatasan hak untuk bergerak juga harus memikirkan dampak sosial dan ekonomi yang akan ditanggung oleh masyarakat rentan ekonomi dan termaginalkan sehingga Pemerintah berkewajiban untuk memberikan kompensasi dan insentif.

\section{UCAPAN TERIMAKASIH}

Terimakasih Penulis ucapkan kepada pihak-pihak terkait yang telah membantu dalam penyelesaian penulisan ini. Fakultas Hukum Universitas Bengkulu, khususnya Pimpinan Fakultas dan Perpustakaan Fakultas Hukum Universitas Bengkulu, yang telah memudahkan dalam mencari referensi untuk menyelesaikan tulisan ini dan seluruh Tim Tentara Biru (Blue Army), Philip C Jessup International Law Moot Court Fakultas Hukum Universitas Bengkulu yang berkompetisi pada putaran dunia (Global Round) Tahun 2020 yang membahas kasus penyebaran virus dalam moot problem: JVID-18. 


\section{DAFTAR PUSTAKA}

Ahsinin, Azkar, Miftah Fadli, Iva Kesuma, Ruben Sumigar, dan Wahyudi Djafar. "Kesenjangan dalam Komitmen dan Implementasi: Mengurai Hambatan Birokratik dalam Penegakan HAM di Indonesia | Perpustakaan ELSAM." Last modified 2017. Diakses Agustus 3, 2021. http://perpustakaan.elsam. or.id/index.php?p=show_detail\&id=15254\& keywords=kesenjangan .

Asshiddiqqie, Jimly. "Komentar atas Perubahan Pasal-Pasal Undang-Undang Dasar 1945." Jakarta: Rajawali Press, 2008, 52.

. "Pokok-Pokok Hukum Tata Negara Indonesia Pasca Reformasi.", Jakarta: PT Bhuana Ilmu Populer, 2007,629-630.

Aust, Anthony. "Modern Law Treaty Practice." Cambridge: Cambridge Press, 2002, 404

Van Ballegooij, Wouter, dan Cecilia Navarra. "An EU mechanism on democracy, the rule of law and fundamental rights." Last modified September 2020. Diakses Juli 30, 2021. https://www.europarl.europa. eu/RegData/etudes/STUD/2020/654186/ EPRS_STU(2020)654186_EN.pdf.

Case, T H E Lawless. "WORLD LAW-THE LAWLESS CASE" 1962: 249 (1961). https:// scholarship.law.duke.edu/cgi/viewcontent. cgi?referer=https://www.google.com/\&https redir $=1 \&$ article $=1804 \&$ context $=\mathrm{dlj}$.

Chandranegara, Ibnu Sina. "Diantara yang terbaik dan terburuk dalam merespon Covid-19 di Asia Tenggara." In Makalah pada webinar New Normal dalam Perspektif Hukum. Solo: Universitas Sebelas Maret Surakarta, 2020.

Cogan, Jacob Katz, dan Jacob K Cogan. "Noncompliance and the International Rule of Law Essay Noncompliance and the International Rule of Law." Yale J. Int'l L 31, no. 1991 (2006). http://digitalcommons.law. yale.edu/yjil\%0Ahttp://digitalcommons.law. yale.edu/yjil/vol31/iss $1 / 4$.

Dumoli, Damos. "Treaties Under Indonesian Law: A comparative Study." Bandung: RosdaKarya, 2014, 21.
European Commission Of Human Rights. "Denmark V Greece 1969." Last modified 1969. Diakses Agustus 3, 2021. https://www. echr.coe.int/Documents/Denmark_Norway_ Sweden_Netherlands_v_Greece_I.pdf.

Guterres, Antonio. "We are all in this Together: Human Rights and COVID-19 Response and Recovery | United Nations." Diakses Agustus 3, 2021. https://www.un.org/en/ un-coronavirus-communications-team/weare-all-together-human-rights-and-covid-19response-and.

Indrayana, Denny. "Indonesian Constitutional Reofrm, 1999-2002: An Evaluation of Constitution-Making in Transition." Jakarta: Kompas Press, 2008, 19.

International Covenant on Civil and Political Rights. "General comment no. 29 states of emergency (article 4)." Last modified Agustus 31, 2001. Diakses Agustus 3, 2021. http://docstore.ohchr.org/SelfServices/ FilesHandler.ashx? enc $=6 \mathrm{QkG} 1 \mathrm{~d} \% 2 \mathrm{FPPRiC}$ AqhKb7yhsjYoiCfMKoIRv2FVaVzRkMjTn jRO\%2Bfud3cPVrcM9YR0iix49nlFOsUPO 4oTG7R\%2Fo7TSsorhtwUUG\%2By2PtslY r5BldM8DN9shT8B8NpbsC\%2B7bODxKR 6zdESeXKjiLnNU\%2BgQ\%3D\%3D.

Justice, International. "Civil Society Access to International Oversight Bodies African Commission on Human and Peoples ' Rights" (n.d.).

Lebret, Audrey. "COVID-19 pandemic and derogation to human rights." Journal of Law and the Biosciences (n.d.): 1-15. https:// rm.coe.int/09000016809cf9a2.

"COVID-19 pandemic and derogation to human rights." Journal of Law and the Biosciences 7, no. 1 (Juli 25, 2020): 1-15. Diakses April 9, 2021. https://academic. oup.com/j1b/article/doi/10.1093/j1b/ lsaa015/5828398.

Livingston, Edward, Karen Bucher, dan Andrew Rekito. "Coronavirus Disease 2019 and Influenza 2019-2020." JAMA - Journal of the American Medical Association 323, no. 12 (2020): 1122. 
Mcadam, Jane. "An Intellectual History of Freedom of Movement in International Law." Melbourne Journal of International Law 12, no. 1 (2011): 1-30. http://law.unimelb.edu. au/_data/assets/pdf_file/0011/1686926/ McAdam.pdf.

MD, Mahfud. "Politik Hukum di Indonesia." Jakarta: Rajawali Press, 2009,7.

Muntarbhorn, Vitit. "The International Covenant on Civil and Political Rights (ICCPR) and Thailand." The Core Human Rights Treaties and Thailand 999, no. 14668 (2016): 141194.

P Trachtman, Joel. "The Future of International Law, Global Government." Cambridge: Cambridge Press, 2014, 139.

Radjenovic, Anja. "Upholding human rights in Europe during the pandemic Derogations under the European Convention of Human," no. September (2020): 12. https://www.europarl.europa.eu/RegData/ etudes/BRIE/2020/652085/EPRS_ BRI\%282020\%29652085_EN.pdf.

Rawls, John. "Justice as Fairness." Bandung: Nusamedia, 1999, 219.

Schabas, William A. "The European Convention on Human Rights: A Commentary" (2015): 1440.

Schreuer, Christoph. "Derogation of Human Rights in Situations of Public Emergency : The Experience of the European Convention on Human Rights Derogation of Human Rights in Situations of European Convention on Human Rights." The Yale Journal of World Public Order 9, no. 1 (1982): 113132. http://digitalcommons.law.yale.edu/ yjil/vol9/iss $1 / 6$.

Shaw, Malcolm. "International Law, Eight Edition."Cambridge: Cambridge Press, 2017, 216.

Sheng, Wang Huei. "Coronavirus disease 2019 (covid-19)." Journal of Internal Medicine of Taiwan 31, no. 2 (2020): 61-66.

Soemantri, Sri. "Prosedur dan Sistem Perubahan Konstitusi." Bandung: Alumni, 2006, 23.
Switzerland. "Revision of the International Health Regulations Comments by the Swiss Government ." Last modified 2004. Diakses Agustus 3, 2021. https://www.who.int/ihr/ revisionprocess/swissIHR.pdf?ua=1.

Syamsyuddin, Aziz. "Proses dan Teknik Penyusunan Undang-Undang." Edisi 2. Jakarta: Sinar Grafika, 2013, 32.

Tigerstrom, Barbara von, dan Kumanan Wilson. "COVID-19 travel restrictions and the International Health Regulations (2005)." BMJ Global Health 5, no. 5 (Mei 17, 2020): 2629. Diakses Juli 30, 2021. https:// www.ncbi.nlm.nih.gov/pmc/articles/ PMC7237384/.

WHO. "Coronavirus disease 2019 (COVID-19) Situation Report - 39." Last modified Februari 28, 2020. Diakses Juli 30, 2021. https://www.who.int/docs/default-source/ coronaviruse/situation-reports/20200228sitrep-39-covid-19.pdf?sfvrsn=5bbf3e7d_4.

"Human Rights and COVID-19: Human Rights Obligations of States During the COVID-19 Pandemic - Human Rights Pulse." Diakses April 9, 2021. https://www. humanrightspulse.com/mastercontentblog/ human-rights-and-covid-19-human-rightsobligations-of-states-during-the-covid-19pandemic.

"Human Rights Dimensions of COVID-19 Response | Human Rights Watch.” Diakses April 22, 2021. https://www.hrw.org/ news/2020/03/19/human-rights-dimensionscovid-19-response\#_Toc35446577.

"Impact assessment of the COVID-19 outbreak on international tourism | UNWTO." Diakses Juni 18, 2021. https://www.unwto. org/impact-assessment-of-the-covid-19outbreak-on-international-tourism.

"Rasio Gini 2020 Naik Jadi 0,385, Covid-19 Buat Ketimpangan Makin Lebar - Ekonomi Bisnis. com.” Diakses Juni 18, 2021. https://ekonomi. bisnis.com/read/20210215/9/1356258/rasiogini-2020-naik-jadi-0385-covid-19-buatketimpangan-makin-lebar. 